\title{
Evaluation of functional results of surgical treatment in children with Legg-Calve-Perthes disease using a portable gait analysis system
}

\author{
A.G. Baindurashvili, I.E Nikityuk, E.A.Kostomarova, E.L. Kononova, D.B. Barsukov, V.E. Baskov
}

H. Turner National Medical Research Center for Children's Orthopedics and Trauma Surgery, Saint Petersburg, Russian Federation

\begin{abstract}
Introduction Typical consequences of Legg-Calve-Perthes disease (LCPD) in its severe stage are pathological changes in the anatomy of the hip joint which lead to functional disorders of the musculoskeletal system, clinically manifested by limp. Objective To study biomechanical characteristics of walking in children with unilateral Legg-Calve-Perthes disease to determine the functional state of the musculoskeletal system after surgical treatment with the use of various methods. Materialand methods Temporal and dynamic parameters of gait were studied in 31 patients with unilateral Legg-Calve-Perthes disease aged from 8 to 13 years old. They were examined two to five years after surgical treatment. In the control group of patients (15 children), varus osteotomy (VO) was performed. In the main group (16 children), triple pelvic osteotomy (TPO) was used. All children were operated in the disease stages II-IV corresponding to the classifications of S.A. Reinberg (1964) and to groups III-IV according to the classification of Catterall (1971). To objectify the study, 18 healthy children of the same age without signs of orthopaedic pathology were examined. Gait biomechanics were studied using the STEDIS complex (Neurosoft LLC, Ivanovo) that includes a set of platformless inert sensors "Neurosens" that record the data on accelerations in three mutually perpendicular planes. The temporal characteristics of the gait cycle and shock loads during walking were recorded. Results After surgical treatment, the biometrics of the support and shock load phases in both groups of children with LCPD did not reach the level of healthy individuals. It indicates preservation of deviations in walking parameters. The least significant asymmetry between the affected and unaffected limb were detected in patients after TPO, compared with patients after VO in whom the asymmetry of temporal parameters in the phase of the forefoot rocker and asymmetry of shock loads in the phases of rocking over the heel and ankle joint were preserved. Conclusion After TPO operations in patients with LCPD, the gait was closer to the physiological one in comparison with patients after $\mathrm{VO}$ who retained a non-optimal motor stereotype. The reasons for such differences in motor activity between the groups of patients lies in the gluteal muscle dysfunction due to high position of the greater trochanter after corrective (varus) femur osteotomy and iatrogenic shortening of the affected limb. Triple pelvic osteotomy lacks these negative effects.
\end{abstract}

Keywords: hip joint, Legg-Calve-Perthes disease, triple pelvic osteotomy, corrective varus osteotomy of the femur, gait analysis

\section{INTRODUCTION}

Legg-Calve-Perthes disease (LCPD) is a challenging problem in pediatric orthopaedics. Its incidence is high among the diseases of the locomotor system and it severely affects the quality of life [1]. The typical consequence of severe LCPD is a multiplanar deformity of the proximal femur associated with high position of the greater trochanter along with a relative shortening of the affected limb [2]. Pathological changes in the hip joint anatomy result in functional locomotor disorders that clinically are manifested by limping gait. The choice of treatment tactics in LCPD children is quite difficult despite the variety of techniques and many years of the accumulated experience. Varus osteotomy of the femur is used in LCPD for improving the centration of the femoral head $[3,4]$. However, it results in additional iatrogenic shortening of the affected limb and in risks of high position of the greater trochanter that lead not only to weakening of the gluteal muscles but also to femoroacetabular impingement $[5,6]$. Triple pelvic osteotomy does not lead to marked deformity of the proximal femur and to additional shortening of the affected limb [7]. New principles of surgical management and improvement of intervention techniques for LCPD patients dictate the necessity to use the methods evaluating not only the anatomy of the affected hip joint but also patients' locomotor functions in order to compare the results after the interventions. Therefore, objective methods to evaluate the parameters of the motor activity are needed [8]. At present, the introduction of modern technologies of gait analysis enables to objectify the functional condition of the locomotor system in the patients after reconstructive interventions on the hip joint $[9,10]$. Nowadays, one of the most accessible and accurate methods for recording gait parameters is contactless systems with application of inert sensors [11, 12] directly on the human body [13]. Fixation of inert sensors on the ankles has been widely used and allows most accurate recording of temporal characteristics of the gait cycle [14]. However, assessment of clinically significant differences in the gait parameters after surgical interventions on the hip joint still remains a serious problem [15]. Capabilities and limitations of the diagnostic techniques have not been fully disclosed. It results in ambiguous interpretation of the results [16]. Therefore, the study of gait features in children with LCPD after surgical management with the use of different techniques has not only practical but also a scientific value.

Purpose of the study was to investigate biomechanical characteristics of walking for assessment of the functional condition of the locomotor system in patients with unilateral LCPD following treatment with different surgical techniques.

Baindurashvili A.G., Nikityuk I.E, Kostomarova E.A., Kononova E.L., Barsukov D.B., Baskov V.E. Evaluation of functional results of surgical treatment in children with Legg-Calve-Perthes disease using a portable gait analysis system. Genij Ortopedii, 2020, vol. 26, no 4, pp. 508-515. DOI 10.18019/1028-4427-2020-26-4-508-515 


\section{MATERIAL AND METHODS}

The study was conducted following the ethical principles of the World Medical Association Declaration of Helsinki on ethical principles for medical research involving human subjects (2013). Temporal and dynamic parameters of gait were studied in 31 patients with unilateral LCPD aged from two to five years. Preoperative study of their walking was not possible as axial load on the affected limb was not allowed. Clinical examination included measurement of limb length discrepancy. Radiographic study of hip joints in anteroposterior views was conducted before and after the surgical management. Center-trochanter distance (CTD) and neck-to-shaft angle (NSA) were determined on both sides. Radiometric data of the affected and healthy joint were compared.

Corrective varus osteotomy of the femur (VO) was performed in 15 children of the control group (Fig. 1). The main group of 16 children underwent triple pelvic osteotomy (TPO) (Fig. 2).
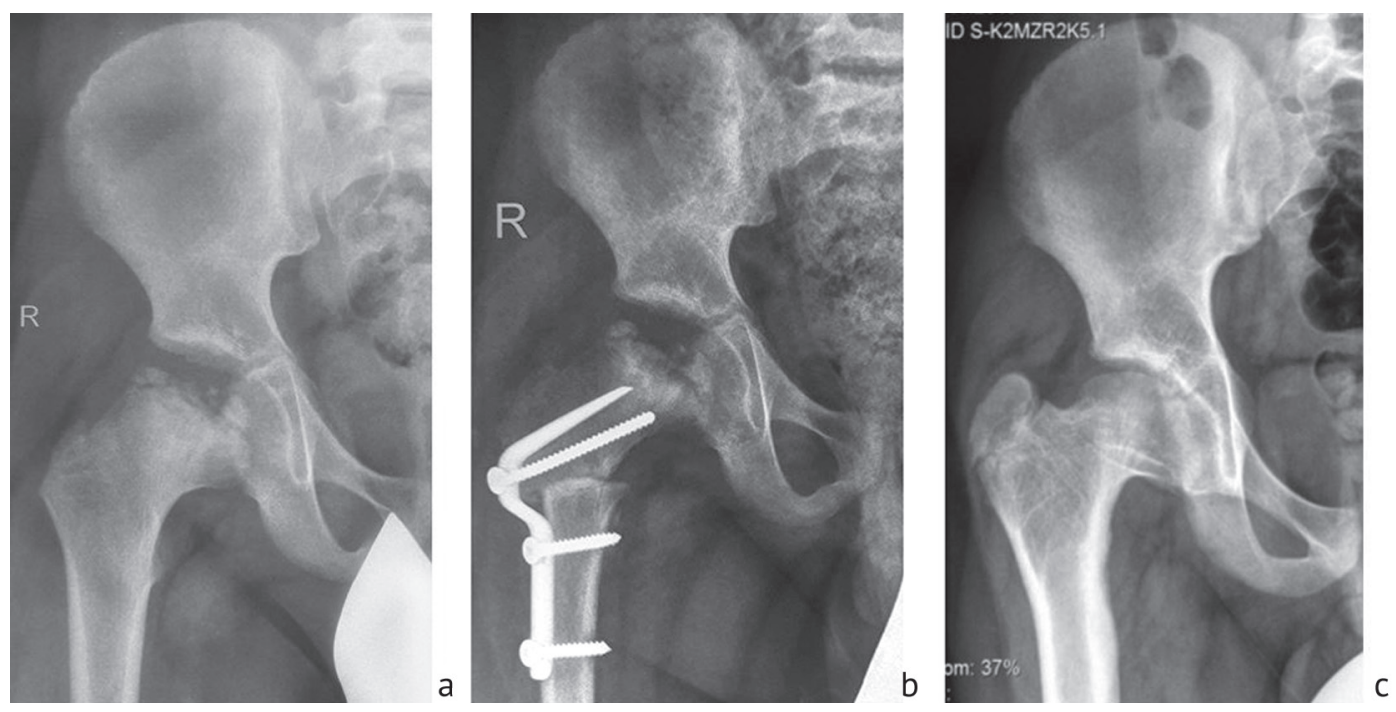

Fig. 1 X-rays of the hip joints in patient R., 9 years old, right-side LCPD: $\boldsymbol{a}$ before surgery; $\boldsymbol{b}$ one months after varus osteotomy on the right side; $c 4$-year outcome of varus osteotomy on the right side
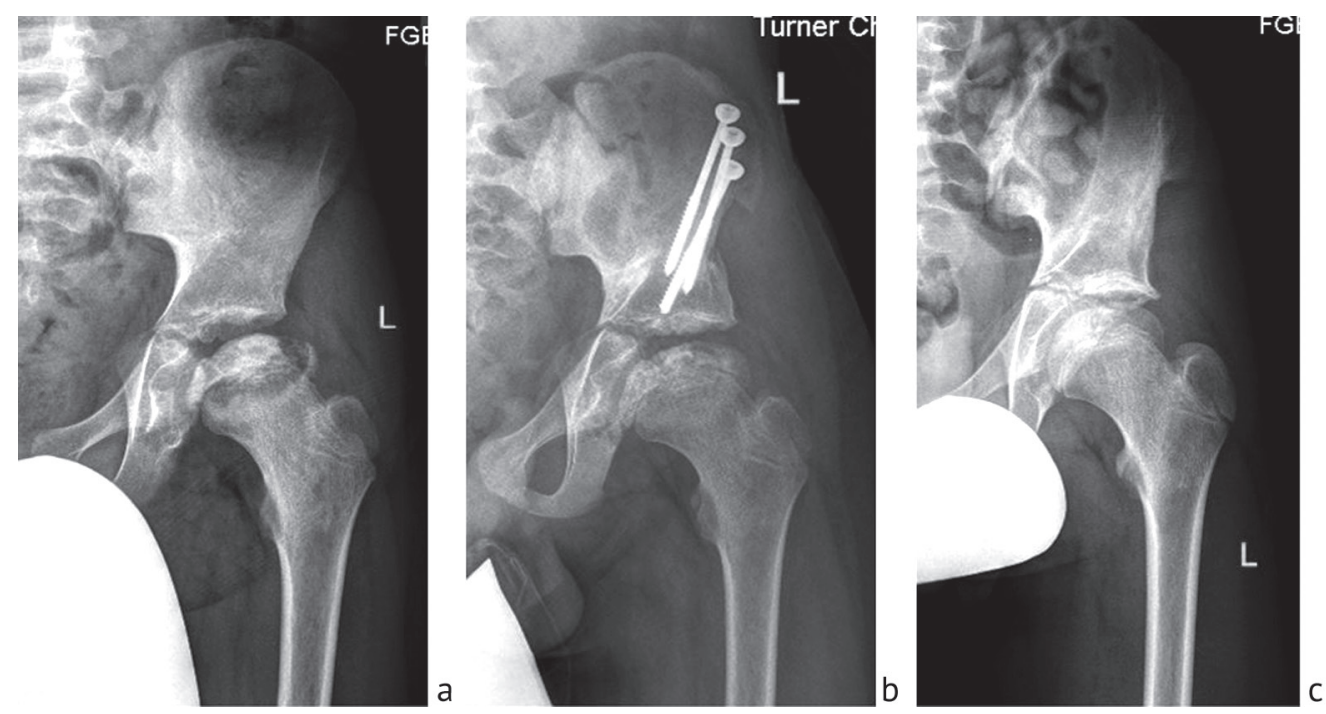

Fig. 2 X-rays of the hip joints in patient A., 8 years old, left-side LCPD: $\boldsymbol{a}$ before surgery; $\boldsymbol{b}$ three months after triple pelvic osteotomy on the left side; $c$ 3-year outcome after triple pelvic osteotomy on the left side 


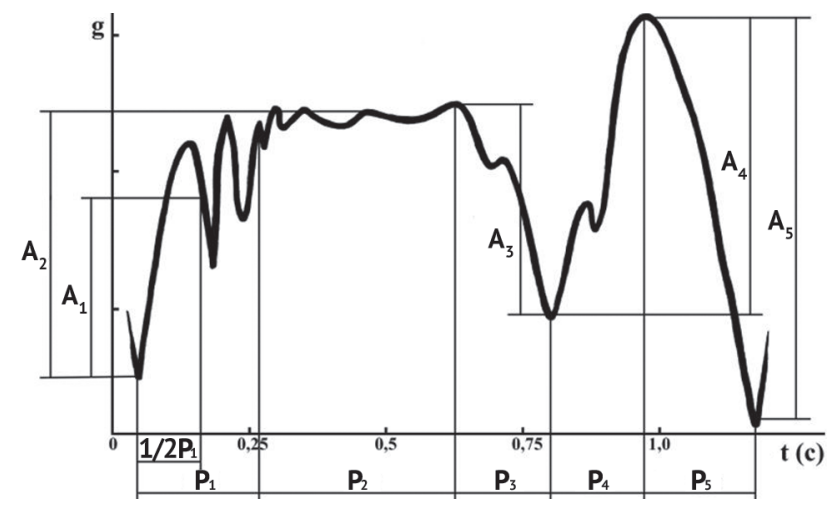

Fig. 3 Diagram of measuring acceleration amplitude (A) and gait phases $(\mathbf{P})$ in the accelerograms of the lower limbs. Horizontal axis - gait cycle phase in seconds (c); vertical axis - low tibial point acceleration amplitude in relative units $(\mathrm{g})$

In the stance the following phases were identified:

$\mathbf{P}_{1}$ - phase of heel loading, from the moment the heel contacts the ground till full body weight on the foot;

$\mathbf{P}_{2}$ - phase of ankle loading, the foot being still while the tibia moves forward till the moment the heel raises from the ground;

$\mathbf{P}_{3}$ - phase of forefoot loading, from the moment heel raises of the ground till the moment the foot leaves the ground.
In the period of swing:

$\mathbf{P}_{4}$ - phase of acceleration, from the moment the foot raises of the ground the limb starts gaining speed for forward advancement;

$\mathbf{P}_{5}$ - phase of deceleration when the limb actively decreases the speed till the foot contacts the ground.

In the accelerograms, each phase from $\mathbf{P}_{\mathbf{1}}$ to $\mathbf{P}_{\mathbf{5}}$ has its peak values of acceleration aplitudes $\mathbf{A}_{\mathbf{1}}-\mathbf{A}_{\mathbf{5}}$.

Asymmetry (\%) for all parameters was calculated between the right and left lower limbs in healthy children, and between the affected and intact limb in children with LCPD.

Statisticalprocessingofthedataobtainedwasperformed with SPSS 11.5 and Statgraphics Centurion 16.2. Hypotheses were checked with variation distribution (Shapiro-Wilk and Kolmogorov-Smirnov tests).

Since the quantitative characteristics did not correspond to the law of normal distribution in the compared groups (at least in one), the MannWhitney U-test was used to compare the values of unrelated samples, and the Wilcoxon test was used for intragroup comparisons. Data were presented as median (Me) with an interquartile range of 25$75 \%\left[\mathrm{Q}_{1}-\mathrm{Q}_{2}\right]$. The threshold level of statistical significance was accepted when the criterion value was $\mathrm{p}<0.05$.

\section{RESULTS}

The relative pre-operative shortening of the lower limb on the affected side in the control group was $0.7 \pm 0.09 \mathrm{~cm}$; in the main group it was $0.7 \pm 0.08 \mathrm{~cm}$. After the VO operations, the difference in the length with the contralateral lower limb significantly increased to $2.5 \pm 0.11 \mathrm{~cm}$ $(\mathrm{p}<0.05)$. After TPO operations, the difference in length remained at the preoperative level $0.9 \pm 0.09 \mathrm{~cm}(\mathrm{p}>0.05)$.

Analysis of the radiographs revealed a change in the relationship between the apex of the greater trochanter and the head of the femur on the affected side in the control group of patients after VO operations (Table 1). It was manifested by a significant increase in CTD of

the affected hip joint compared with the healthy side $(p=0.022)$. Moreover, there was a significant decrease in the NSA value after surgery $(p=0.012)$ in this group of patients. There were no such anatomical changes in the main group of patients after TPO operations.

Biomechanical studies in patients with LCPD after surgical treatment revealed asymmetry in the gait characteristics between the affected and unaffected lower extremities that was of different severity depending on the operation performed and was detected both during the support period (Tables 2, 3) and during the swing (Table 4, 5).

Table 1

Dynamics of radiometric parameters of the hip joints in children with unilateral LCPD

\begin{tabular}{|c|c|c|c|c|c|c|}
\hline \multirow[b]{3}{*}{ Parameter } & \multirow{3}{*}{$\begin{array}{l}\text { Healthy side (1) } \\
\text { Me [Q1 - Q2] } \\
\text { n=31 }\end{array}$} & \multicolumn{4}{|c|}{ Affected side } & \multirow[b]{3}{*}{$p$} \\
\hline & & \multicolumn{2}{|c|}{ Control group (VO) } & \multicolumn{2}{|c|}{ Main group (TPO) } & \\
\hline & & $\begin{array}{c}\text { Before surgery } \\
\text { (2) Me [Q1 - Q2] } \\
n=15\end{array}$ & $\begin{array}{c}\text { After surgery (3) Me } \\
{[\mathrm{Q} 1-\mathrm{Q} 2]} \\
\mathrm{n}=15 \\
\end{array}$ & $\begin{array}{c}\text { Before surgery } \\
\text { (4) Me [Q1 - Q2] } \\
n=16\end{array}$ & $\begin{array}{c}\text { After surgery (5) Me } \\
{[\mathrm{Q} 1-\mathrm{Q} 2]} \\
\mathrm{n}=16\end{array}$ & \\
\hline CTD, mm & $-1.0[-9.8-6.9]$ & $3.3[0-8.0]$ & $11.8[5.3-15.9]$ & $2.7[0-6.6]$ & $4.8[2.8-10.2]$ & $\begin{array}{l}p^{1-2}=0.336 \\
p^{1-4}=0.363 \\
p^{2-3}=\mathbf{0 . 0 2 2} \\
p^{4-5}=0.218\end{array}$ \\
\hline $\begin{array}{l}\text { NSA, } \\
\text { degrees }\end{array}$ & 137 [131-145] & $136[127-145]$ & $122[112-130]$ & $138[128-153]$ & $137[126-151]$ & $\begin{array}{l}p^{1-2}=0.863 \\
p^{1-4}=0.755 \\
\boldsymbol{p}^{2-3}=\mathbf{0 . 0 1 2} \\
p^{4-5}=0.819\end{array}$ \\
\hline
\end{tabular}

Notes: $p^{1-2 ; 1-4}$ - significance of differences between the groups (Mann-Whitney test); $p^{2-3 ; 4-5}$ - signficance of differences in the group before and after the intervention (Wilcoxon test), CTD - center-trochanter distance; NSA- neck-to-shaft angle 
Table 2

Indicators of the duration of the gait cycle phases in the period of support in healthy children and patients with unilateral LCPD after surgical treatment

\begin{tabular}{|c|c|c|c|c|c|c|}
\hline \multirow{3}{*}{ Groups } & \multicolumn{6}{|c|}{ Stance phase } \\
\hline & \multicolumn{2}{|c|}{ phase $\mathbf{P}_{1}(\%)$} & \multicolumn{2}{|c|}{ Phase $\mathbf{P}_{2}(\%)$} & \multicolumn{2}{|c|}{ Phase $\mathbf{P}_{3}(\%)$} \\
\hline & left & right & left & right & left & right \\
\hline $\begin{array}{l}\text { Healthy }(1) \\
\text { Me }\left[\mathrm{Q}_{1}-\mathrm{Q}_{2}\right] \mathrm{n}=18\end{array}$ & $\begin{array}{c}18.4 \\
{[16.3-21.1]} \\
\end{array}$ & $\begin{array}{c}18.2 \\
{[17.9-18.4]} \\
\end{array}$ & $\begin{array}{c}31.6 \\
{[30.2-32.5]} \\
\end{array}$ & $\begin{array}{c}31.6 \\
{[30.2-31.6]} \\
\end{array}$ & $\begin{array}{c}14.3 \\
{[12.8-15.0]} \\
\end{array}$ & $\begin{array}{c}12.8 \\
{[12.2-15.0]}\end{array}$ \\
\hline Asymmetry, \% & \multicolumn{2}{|c|}{$2.5 \pm 2.61(p=0.714)$} & \multicolumn{2}{|c|}{$0.4 \pm 1.08(p=0.961)$} & \multicolumn{2}{|c|}{$4.9 \pm 2.81(p=0.380)$} \\
\hline Side & unaffected & affected & unaffected & affected & unaffected & affected \\
\hline $\begin{array}{l}\text { После КВОБ (2) } \\
\text { Мe }\left[\mathrm{Q}_{1}-\mathrm{Q}_{2}\right] \mathrm{n}=15\end{array}$ & $\begin{array}{c}28.6 \\
{[25.0-31.0]} \\
\end{array}$ & $\begin{array}{c}27.9 \\
{[21.8-31.1]} \\
\end{array}$ & $\begin{array}{c}31.1 \\
{[26.3-34.6]} \\
\end{array}$ & $\begin{array}{c}37.5 \\
{[34.3-38.7]} \\
\end{array}$ & $\begin{array}{c}9.1 \\
{[4.8-11.1]} \\
\end{array}$ & $\begin{array}{c}4.4 \\
{[2.9-5.0]}\end{array}$ \\
\hline Асимметрия (\%) & \multicolumn{2}{|c|}{$17.3 \pm 12.0(p=0.623)$} & \multicolumn{2}{|c|}{$-17.8 \pm 5.96(p=\mathbf{0 . 0 0 1})$} & \multicolumn{2}{|c|}{$51.7 \pm 9.32(\boldsymbol{p}=\mathbf{0 . 0 0 4})$} \\
\hline Side & unaffected & affected & unaffected & affected & unaffected & affected \\
\hline $\begin{array}{l}\text { After VO (3) } \\
\text { Me }\left[Q_{1}-Q_{2}\right] n=16\end{array}$ & $\begin{array}{c}27.9 \\
{[27.0-31.7]}\end{array}$ & $\begin{array}{c}27.0 \\
{[24.4-27.5]}\end{array}$ & $\begin{array}{c}25.0 \\
{[22.9-27.3]}\end{array}$ & $\begin{array}{c}29.7 \\
{[28.6-30.0]}\end{array}$ & $\begin{array}{c}13.5 \\
{[11.4-16.7]}\end{array}$ & $\begin{array}{c}11.4 \\
{[9.8-16.2]}\end{array}$ \\
\hline Asymmetry (\%) & \multicolumn{2}{|c|}{$8,1 \pm 5,42(\boldsymbol{p}=\mathbf{0 , 0 2 2})$} & \multicolumn{2}{|c|}{$-9,1 \pm 5,61(\boldsymbol{p}=\mathbf{0 , 0 0 3})$} & \multicolumn{2}{|c|}{$12,8 \pm 11,7(p=0,122)$} \\
\hline $\begin{array}{l}\text { Mann-Whitney test, } \\
\text { p-value }\end{array}$ & $\begin{array}{l}p^{1-2}<0.001 \\
p^{1-3}<0.001 \\
\end{array}$ & $\begin{array}{l}p^{1-2}=0.004 \\
p^{1-3}<0.001\end{array}$ & $\begin{array}{l}p^{1-2}=0.147 \\
\boldsymbol{p}^{\mathbf{1 - 2}}<\mathbf{0 . 0 0 1}\end{array}$ & $\begin{array}{l}p^{1-2}=\mathbf{0 . 0 0 6} \\
p^{1-3}=\mathbf{0 . 0 0 1}\end{array}$ & $\begin{array}{l}\boldsymbol{p}^{\mathbf{1 - 2}}<\mathbf{0 . 0 0 1} \\
p^{1-3}=0.717 \\
\end{array}$ & $\begin{array}{l}\boldsymbol{p}^{\mathbf{1 - 2}}<\mathbf{0 . 0 0 1} \\
p^{1-3}=0.153\end{array}$ \\
\hline
\end{tabular}

Notes: $p$ - significance of differences between the contralateral limbs; $p^{1-2 ; 1-3}-$ significance of difference between the groups. The sign

"-" means exceeded values on the affected side compared to the healthy one

Table 3

Indicators of shock loads on the lower limb in the stance in healthy children and patients with unilateral LCPD after surgical treatment

\begin{tabular}{|c|c|c|c|c|c|c|}
\hline \multirow{2}{*}{ Group } & \multicolumn{6}{|c|}{ Shock load in the support period } \\
\hline & \multicolumn{2}{|c|}{$\mathbf{A}_{1}(\mathrm{~g})$} & \multicolumn{2}{|c|}{$\mathbf{A}_{2}(\mathrm{~g})$} & \multicolumn{2}{|c|}{$\mathbf{A}_{3}(\mathrm{~g})$} \\
\hline Side & left & right & left & right & left & right \\
\hline $\begin{array}{l}\text { Healthy }(1) \\
\text { Me [Q1 - Q2] } \mathrm{n}=18\end{array}$ & $\begin{array}{c}12.0 \\
{[10.0-13.0]}\end{array}$ & $\begin{array}{c}11.0 \\
{[10.0-12.0]}\end{array}$ & $\begin{array}{c}19.0 \\
{[16.0-20.0]}\end{array}$ & $\begin{array}{c}18.0 \\
{[16.0-19.0]}\end{array}$ & $\begin{array}{c}13.0 \\
{[10.0-13.0]}\end{array}$ & $\begin{array}{c}11.0 \\
{[10.0-12.0]}\end{array}$ \\
\hline Asymmetry $(\%)$ & \multicolumn{2}{|c|}{$3.9 \pm 5.89(p=0.531)$} & \multicolumn{2}{|c|}{$3.9 \pm 3.61(p=0.378)$} & \multicolumn{2}{|c|}{$7.1 \pm 3.55(p=0.142)$} \\
\hline Side & unaffected & affected & unaffected & affected & unaffected & affected \\
\hline $\begin{array}{l}\text { After VO (2) } \\
\text { Me [Q1 - Q2] n = 15 }\end{array}$ & $\begin{array}{c}18.0 \\
{[15.0-21.0]} \\
\end{array}$ & $\begin{array}{c}10.0 \\
{[9.0-10.0]}\end{array}$ & $\begin{array}{c}16.0 \\
{[15.0-21.0]}\end{array}$ & $\begin{array}{c}10.0 \\
{[8.0-12.0]}\end{array}$ & $\begin{array}{c}10.0 \\
{[7.0-11.0]}\end{array}$ & $\begin{array}{c}12.0 \\
{[7.0-16.0]}\end{array}$ \\
\hline Asymmetry $(\%)$ & \multicolumn{2}{|c|}{$59.1 \pm 15.08(p<0.001)$} & \multicolumn{2}{|c|}{$45.6 \pm 11.48(p<0.001)$} & \multicolumn{2}{|c|}{$-18.4 \pm 15.44(p=0.101)$} \\
\hline Side & unaffected & affected & unaffected & affected & unaffected & affected \\
\hline $\begin{array}{l}\text { After VO (3) } \\
\text { Me [Q1 - Q2] n = } 16\end{array}$ & $\begin{array}{c}12.0 \\
{[10.0-14.0]}\end{array}$ & $\begin{array}{c}12.0 \\
{[10.0-14.0]}\end{array}$ & $\begin{array}{c}16.0 \\
{[14.0-24.0]}\end{array}$ & $\begin{array}{c}13.0 \\
{[12.0-15.0]}\end{array}$ & $\begin{array}{c}8.0 \\
{[6.0-11.0]}\end{array}$ & $\begin{array}{c}12.0 \\
{[10.0-14.0]}\end{array}$ \\
\hline Asymmetry $(\%)$ & \multicolumn{2}{|c|}{$14.3 \pm 3.48(p=0.119)$} & \multicolumn{2}{|c|}{$30,4 \pm 5.47(\boldsymbol{p}=\mathbf{0 . 0 0 1})$} & \multicolumn{2}{|c|}{$-27.6 \pm 12.25(\boldsymbol{p}=\mathbf{0 . 0 1 6})$} \\
\hline $\begin{array}{l}\text { Mann-Whitney tes, } \\
\text { p-value }\end{array}$ & $\begin{array}{l}p^{1-2}<\mathbf{0 . 0 0 1} \\
p^{1-3}=0.501\end{array}$ & $\begin{array}{l}\boldsymbol{p}^{\mathbf{1 - 2}}=\mathbf{0 . 0 4 2} \\
p^{1-3}=0.223\end{array}$ & $\begin{array}{l}p^{1-2}=0.443 \\
p^{1-3}=0.904\end{array}$ & $\begin{array}{l}p^{1-2}<0.001 \\
p^{1-3}<0.001\end{array}$ & $\begin{array}{l}p^{1-2}=0.007 \\
p^{1-3}=0.005\end{array}$ & $\begin{array}{l}p^{1-2}=0.718 \\
p^{1-3}=0.635\end{array}$ \\
\hline
\end{tabular}

Note: $p$ significance of difference in the group between the contralateral limbs; $p^{1-2 ; 1-3}$-significance of differences between groups. The "-" sign means exceeded values on the affected side compared to the healthy one

Table 4

Indicators of phase duration in the swing in healthy children and patients with unilateral LCPD after surgical treatment

\begin{tabular}{|c|c|c|c|c|}
\hline \multirow{2}{*}{ Groups } & \multicolumn{4}{|c|}{ Swing phase } \\
\hline & \multicolumn{2}{|c|}{ Acceleration $\mathbf{P}_{4}(\%)$} & \multicolumn{2}{|c|}{ Deceleration $\mathbf{P}_{5}(\%)$} \\
\hline Side & left & right & left & right \\
\hline $\begin{array}{l}\text { Healthy }(1) \\
\text { Me [Q1 - Q2] } \mathrm{n}=18\end{array}$ & $16.3[13.6-17.1]$ & $15.9[14.3-16.3]$ & $17.9[17.1-18.4]$ & $18.4[17.9-18.6]$ \\
\hline Asymmetry (\%) & \multicolumn{2}{|c|}{$4.3 \pm 2.72(p=0.380)$} & \multicolumn{2}{|c|}{$3.1 \pm 2.16(p=0.049)$} \\
\hline Side & unaffected & affected & unaffected & affected \\
\hline $\begin{array}{l}\text { After VO (2) } \\
\text { Me [Q1 - Q2] n = } 15\end{array}$ & $14.3[13.2-17.3]$ & $13.9[11.4-14.5]$ & $19.2[16.7-21.4]$ & $17.8[17.1-21.8]$ \\
\hline Asymmetry (\%) & \multicolumn{2}{|c|}{$-1.5 \pm 7.95(p=0.912)$} & \multicolumn{2}{|c|}{$0.5 \pm 8.1(p=0.668)$} \\
\hline Side & unaffected & affected & unaffected & affected \\
\hline $\begin{array}{l}\text { After TPO (3) } \\
\text { Me [Q1 - Q2] } n=16\end{array}$ & $11.6[8.6-16.2]$ & $13.5[12.5-14.3]$ & $20.9[18.2-21.6]$ & $19.5[18.9-21.6]$ \\
\hline Asymmetry (\%) & \multicolumn{2}{|c|}{$-7.3 \pm 16.64(p=0.240)$} & \multicolumn{2}{|c|}{$0.1 \pm 3.12(p=0.661)$} \\
\hline $\begin{array}{l}\text { Mann-Whitney test, } \\
\text { p-value }\end{array}$ & $\begin{array}{l}p^{1-2}=0.257 \\
p^{1-3}=\mathbf{0 . 0 0 1}\end{array}$ & $\begin{array}{l}p^{1-2}=0.079 \\
p^{1-3}=\mathbf{0 . 0 1 1}\end{array}$ & $\begin{array}{l}p^{1-2}=0.257 \\
p^{1-3}<\mathbf{0 . 0 0 1}\end{array}$ & $\begin{array}{l}p^{1-2}=0.513 \\
p^{1-3}<\mathbf{0 . 0 0 1}\end{array}$ \\
\hline
\end{tabular}

Notes: $p$ - significance of differences between the contralateral limbs; $p^{1-2 ; 1-3}$ - significance of differences between the groups. The sign

"-" means exceeded values on the affected side compared to the healthy one 
Table 5

Indicators of shock loads on the lower limb in the swing in healthy children and patients with unilateral LCPD after surgical treatment

\begin{tabular}{|c|c|c|c|c|}
\hline \multirow{3}{*}{ Groups } & \multicolumn{4}{|c|}{ Shock load in the swing } \\
\hline & \multicolumn{2}{|c|}{ Acceleration $\mathbf{A}_{4}(\mathrm{~g})$} & \multicolumn{2}{|c|}{ Deceleration $\mathbf{A}_{5}(\mathrm{~g})$} \\
\hline & left & right & left & right \\
\hline $\begin{array}{l}\text { Healthy }(1) \\
\text { Me [Q1 - Q2] } \mathrm{n}=18\end{array}$ & $21.0[20.0-23.0]$ & $21.0[20.0-23.0]$ & $26.0[24.0-26.0]$ & $26.0[24.0-29.0]$ \\
\hline Asymmetry (\%) & \multicolumn{2}{|c|}{$4.4 \pm 2.77(\mathrm{p}=0.533)$} & \multicolumn{2}{|c|}{$2.5 \pm 2.65(\mathrm{p}=0.619)$} \\
\hline Side & unaffected & affected & unaffected & affected \\
\hline $\begin{array}{l}\text { After VO (2) } \\
\text { Me [Q1 - Q2] n = } 15\end{array}$ & $19.0[15.0-21.0]$ & $19.0[18.0-23.0]$ & $25.0[23.0-28.0]$ & $18.0[13.0-19.0]$ \\
\hline Asymmetry $(\%)$ & \multicolumn{2}{|c|}{$3.1 \pm 8.98(\mathrm{p}=0.491)$} & \multicolumn{2}{|c|}{$42.4 \pm 7.42(p<0.001)$} \\
\hline Side & unaffected & affected & unaffected & affected \\
\hline $\begin{array}{l}\text { After TPO (3) } \\
\text { Me [Q1 - Q2] n = } 16\end{array}$ & $19.0[18.0-22.0]$ & $21.0[19.0-23.0]$ & $25.0[23.0-27.0]$ & $19.0[17.0-21.0]$ \\
\hline Asymmetry $(\%)$ & \multicolumn{2}{|c|}{$1.4 \pm 6.99(\mathrm{p}=0.170)$} & \multicolumn{2}{|c|}{$30.5 \pm 4.28(\mathrm{p}<0.001)$} \\
\hline $\begin{array}{l}\text { Mann-Whitney test, } \\
\text { p-value }\end{array}$ & $\begin{array}{l}\boldsymbol{p}^{\mathbf{1 - 2}}=\mathbf{0 . 0 0 5} \\
p^{1-3}=0.092\end{array}$ & $\begin{aligned} \boldsymbol{p}^{\mathbf{1 - 2}} & =\mathbf{0 . 0 3 3} \\
p^{1-3} & =0.577\end{aligned}$ & $\begin{array}{l}p^{1-2}=0.007 \\
p^{1-3}<0.001\end{array}$ & $\begin{array}{l}p^{1-2}<0.001 \\
p^{1-3}=0.008\end{array}$ \\
\hline
\end{tabular}

Notes: $p$-significance of differences between the contralateral limbs; $p^{1-2 ; 1-3}-$ significance of differences between the groups. The sign "-" means exceeded values on the affected side compared to the healthy one

When interpreting the data, it was taken into account that the indicators of physiological asymmetry of the parameters of the gait cycle for the right and left lower extremities in a healthy person may reach $5 \%$ [20]. Therefore, the functional asymmetry of walking parameters that exceeded $5 \%$ was regarded as pathological [21]. An important parameter of the gait cycle is the period of single support, which is considered the only time interval characterizing the isolated function of one limb. Assessment of the asymmetry of this particular time interval is most indicative for comparing the functional activity of the contralateral limbs [22].

The present study revealed an insignificant asymmetry of the indicators in the period of single support between the contralateral lower extremities in healthy children (1.9 $\pm 0.31 \%$ ). In patients after VO operations, a significant increase in the asymmetry of indicators at the single support stance was found, up to $9.9 \pm 2.52 \%$, while in patients after TPO, this indicator was increased only to $7.3 \pm 1.66 \%$, which did not differ significantly from the normal five percent value. However, the duration of this period was significantly reduced on the affected side in both groups of patients, resulting from unload of the affected lower limb at the expense of the functional tension of the unaffected one. Thus, in patients after TPO, despite the asymmetry in the single support, the support function of the lower extremities was quite equal. At the same time, in patients after $\mathrm{VO}$ operations, the functional capability of the affected limb to maintain body weight remained decreased, while there is a redistribution of functions between the contralateral sides, the healthy lower limb performs mainly the function of support while the limb on the side of VO the transfer function.

According to Tables 1 and 2, the duration of the heel rocking $\left(\mathbf{P}_{1}\right)$ on the contralateral extremities was significantly increased after surgical treatment in both groups. Thereby, the $\mathbf{P}_{1}$ value on the healthy side exceeded the value on the healthy side, insignificantly but substantively in children after VO operations, and significantly but not substantively in children after TPO. That is, the asymmetry of the temporal indicators in $\mathbf{P}_{1}$ phase was sharply increased in the patients after VO operations compared with the patients after TPO. In this phase, the $\mathbf{A}_{1}$ value, shock load on the intact limb, was sharply elevated in the VO patients compared with the norm due to significant reduction in the loading on the affected limb. On the contrary, in the patients after TPO, the increase in the shock load on an intact heel was not revealed and the asymmetry of load on the lower extremities was insignificant and non-substantive. It confirms their equal functionality and a more physiological organization of the gait motions.

In $\mathbf{P}_{2}$ phase of ankle rocking, the temporal indicators were evenly decreased against the norm in both extremities of the TPO patients and had a compensatory character due to prolonged $\mathbf{P}_{1}$ phase. In VO-patients, there was no clear tendency in the change of $\mathrm{P} 2$ phase duration that implies incoordination of gait phases in the period of stance. Thereby, in contrast to $\mathbf{P}_{\mathbf{1}}$ phase, the asymmetry of phase $\mathbf{P}_{2}$ indicators of the contralateral sides changes the sign to the opposite: the duration on the affected side exceeds the one on the intact side in both LCPD groups. Prolongation of the temporal interval of the heel rocking on the affected side in both groups of patients may be explained by an adaptive response of the locomotor system intended to a smoother changes in axial loads on the lower extremities, and consequently, on the affected hip joint during walking. Although the asymmtry of the temporal indices between the contralateral limbs was retained in both groups of patients, the children after the TPO interventions had a significantly lower value.

Thereby, the axial load $\mathbf{A}_{\mathbf{2}}$ in the phase $\mathbf{P}_{\mathbf{2}}$ on the affected lower extremity was reduced as compared with the intact side in patients of both groups. It means that a sparing mechanism of weight-bearing performance is realized in all LCPD patients, which is aimed at unloading of the affected limb (Fig. 4). 

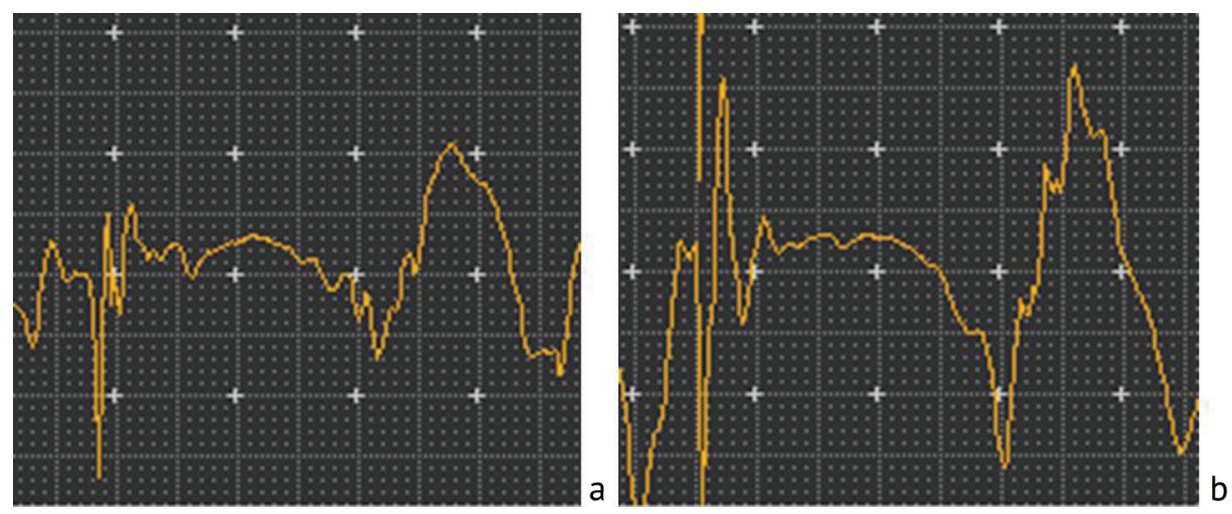

Fig. 4 Accelerograms of the lower extremities in patient R., 9 years old, right-side LCPD (4 years after corrective varus osteotomy of the right femur). Changes in shock load in the area of the lower tibial anthropometric point: $\boldsymbol{a}$ affected limb, $\boldsymbol{b}$ unaffected limb. In the rocker phase through the ankle joint, the axial load $\mathbf{A}_{2}$ on the affected limb is sharply reduced compared to the healthy side

Phase $\mathbf{P}_{3}$ duration (forefoot rocking) is sharply decreased in the patients after VO operations as compared with the norm, both on the affected and unaffected sides $(\mathrm{p}<0.05)$. Moreover, the patients took more time for forefoot rocking on the affected side compared with the unaffected one. Patients after TPO show a more balanced walking in $\mathbf{P}_{3}$ phase as their temporal idicators retain stability and did not differ significantly from the values in healthy subjects $(p<0.05)$. Both groups showed a decrease in the strength of the "anterior push" $\mathbf{A}_{3}$ of the unaffected lower limb as compared with the norm. This fact may be explained by the need of compensatory decrease in the energy consumption of the healthy limb in the final phase of the support period during which the limb performs an excessive work due to increased loading. It proves the preservation of the locomotor system adaptive potential in both LCPD groups, irrespective of the surgical technique used.

In the swing period, the patients of both groups in contrast to healthy subjects showed a considerably shorter acceleration phase $\mathbf{P}_{4}$ compared with the deceleration $\mathbf{P}_{5}$ both for the unaffected and affected sides. However, pathological "hip hiking" was not observed as far as the speed $\mathbf{A}_{4}$ of affected and healthy limb lifting did not exceed the normal values. Moreover, an important factor is an insignificant asymmetry of these indicators between the affected and unaffected sides. However, the total duration of the acceleration and deceleration phases in the swing are similar in the patients of both groups and do not differ from the healthy subjects.

Nevertheless, patients after VO surgery show decreased deceleration efforts of positioning the foot on the ground (A5) on the affected side in $\mathbf{P}_{5}$ phase compared with the healthy children. In the patients after TPO, the deceleration force of the affected limb before the initial contact with the ground was more pronounced. That is, in the patients after TPO, the affected limb decreases the speed more actively by the moment of the initial contact and provides a smoother contact with a horisontal support. Thus, both LCPD groups feature an adaptive mechanism that realizes the need to decrease the shock load on the affected limb for preparation to the subsequent stance but it of different force.

\section{DISCUSSION}

The analysis of the gait parameters in patients with LCPD of both groups revealed deviations from the norm in the temporal characteristics of the gait cycle and in the magnitude of shock loads on the lower limbs of varying severity. Taking into account the fact that a relatively short period passed after surgical treatment, two to 5 years, the walking of patients of both groups still differed from that of healthy children. It should be noted that delayed recovery of locomotion functions in the post-operative period is characteristic of patients with hip joint pathology $[23,24]$. In both groups of patients, an asymmetry in gait parameters between the affected and unaffected sides was revealed, which is characteristic of unilateral pathology of the hip joint [25] and is an important diagnostic indicator of a decrease in the child's ability to normal locomotion [26]. At the same time, a quantitative analysis of the functional asymmetry of the lower limbs is extremely important for assessing the severity of deviations of the musculoskeletal system during orthopedic treatment [27].
Although the deviation of gait parameters from normal values took place in both groups of patients, the asymmetry in the $\mathbf{P}_{3}$ phase of forefoot rocker and shock loads $\mathbf{A}_{1}$ and $\mathbf{A}_{2}$ were sharply increased after $\mathrm{VO}$ operations. They indicate a pronounced support function insufficiency of the affected limb and, consequently, more severe disorders in the walking stereotype in such patients. In this case, the decrease in the functional capabilities of the musculoskeletal system is caused by the dysfunction of the gluteal muscles on the affected side due to elevation of the greater trochanter positioning after corrective (varus) osteotomy of the femur. It is confirmed by a significant increase in the CTD of the hip joint after VO due to a reduced NSA value after the intervention.

Iatrogenic shortening of the affected limb might be an additional factor aggravating the functional asymmetry of the contralateral lower extremities in patients after the VO operation, which significantly increased after the surgery. The increased limb shortening is due to the 
technique of VO performance [28]. It is known that the temporal parameters of locomotion are violated in unilateral lower limb shortening [29]. The activity and coordination of muscle work [30] change and affects the walking stereotype. It should be noted that the marked decrease in shock load on the lower extremity of the affected side observed by walking in the patients after the VO operation, although it is an indicator of abnormality, may, however, be considered as an adequate adaptive response of the musculoskeletal system contributing to the improvement of the shockabsorbing effect of the lower limb.

Patients after TPO did not have pronounced signs of impaired walking biomechanics but showed an adaptive motor stereotype close to the physiological one.

Among other facts, it is necessary to consider such a feature of the child's musculoskeletal system as plasticity due to which compensatory changes develop in the kinematic chains of a growing organism with lower limb pathology [31]. All components of the musculoskeletal system are able to interact, and in favorable conditions of the child's growth it leads to steady positive changes in the biodynamics of locomotion [32] and to the formation of an adequate motor stereotype [33]. Therefore, compared with VO, the TPO operation is more optimal for patients from the point of view of biomechanics, since it does not interfere with the formation of their adaptive motor reactions, and therefore, it is more correct not only anatomically but also functionally. Thus, the function of the affected hip joint after TPO is restored more adequately compared with VO.

These facts show various compensatory and adaptive capabilities of the musculoskeletal system of patients with unilateral LCPD in providing motor activity after surgical treatment which depends on the method of surgical intervention. Biometrics of gait phases and shock loads enables to objectively describe the functional state of the musculoskeletal system and reveal the better results after triple pelvic osteotomy operations compared with corrective (varus) osteotomy of the femur.

\section{CONCLUSION}

1. Biomechanical gait analysis using accelerometers enables to objectively assess the motor abilities of patients with Legg-Calve-Perthes disease and to compare the results of various methods of surgical treatment.

2. After surgical treatment, the biometrics of the phases of support and stress loads in both groups of children with Legg-Calve-Perthes disease did not reach the same level as in healthy individuals. It indicates that there are persistent deviations in gait parameters in patients after surgical treatment. However, the gait of patients with LPCD after triple osteotomy was closer to the physiological one by the total of parameters in comparison with patients after corrective (varus) femur osteotomy.

3. A significant cause of impaired walking after corrective (varus) femoral osteotomy is dysfunction of the gluteal muscles on the affected side, aggravated by additional iatrogenic varisation of the femoral neck and shortening of the lower limb produced by the operation. Triple pelvic osteotomy is devoid of the negative effects listed.

Source of funding The study was conducted within the framework of the State Assignment of the Ministry of Health of the Russian Federation No AAAA-A18-118122690158-2.

Conflict of interest The authors declare no obvious or potential conflicts of interest related to the publication of this article.

Ethical statement The study was conducted in accordance with the ethical standards of the Declaration of Helsinki of the World Medical Association as amended by the Ministry of Health of Russia, approved by the ethical committee of the Turner Institute of the Ministry of Health of Russia (protocol No. 19-2 of 04.12.2019). The authors obtained written and voluntary consent of patients (or their legal representatives) to participate in the study and publish medical data.

\section{REFERENCES}

1. Barsukov D.B., Krasnov A.I., Baskov V.E., Pozdnikin I.Iu., Voloshin S.Iu., Baskaeva T.V., Bortulev P.I., Aleksandrenko I.P. Korrigiruiushchaia osteotomiia bedra v kompleksnom lechenii detei s bolezniu Legga-Kalve-Pertesa [Corrective femoral osteotomy in the complex treatment of children with Legg-Calvé-Perthes' disease]. Genij Ortopedii, 2017, vol. 23, no. 1, pp. 63-70. (in Russian) DOI: 10.18019/1028-4427-2017-23-1-63-70

2. Shohat N., Gilat R., Shitrit R., Smorgick Y., Beer Y., Agar G. A long-term follow-up study of the clinical and radiographic outcome of distal trochanteric transfer in Legg-Calvé-Perthes' disease following varus derotational osteotomy. Bone Joint J., 2017, vol. 99-B, no. 7, pp. 987-992. DOI: 10.1302/0301-620X.99B7.BJJ-2016-1346.R2

3. Elzohairy M.M. Short follow-up evaluation of proximal femoral varus osteotomy for treatment of Legg-Calvé-Perthes disease. J. Orthop. Traumatol., 2016, vol. 17 , no. 4 , pp. 345-351. DOI: $10.1007 /$ s10195-016-0412-0

4. Aydin B.K., Sofu H., Konya M.N., Er T., Sahin V. Clinical and radiographic outcomes after femoral varus derotation osteotomy for LeggCalvé-Perthes disease at 25 years follow-up: what are the determinants of outcome in the long term? Hip Int., 2016, vol. 26, no. 3, pp. 301-306. DOI: 10.5301/hipint.5000329

5. Leroux J., Abu Amara S., Lechevallier J. Legg-Calvé-Perthes disease. Orthop. Traumatol. Surg. Res., 2018, vol. 104, no. 1S, pp. S107-S112. DOI:10.1016/j.otsr.2017.04.012

6. Kim H.K., da Cunha A.M., Browne R., Kim H.T., Herring J.A. How much varus is optimal with proximal femoral osteotomy to preserve the femoral head in Legg-Calvé-Perthes disease? J. Bone Joint Surg. Am., 2011, vol. 93, no. 4, pp. 341-347. DOI: 10.2106/JBJS.J.00830

7. Dementsov A.B. Bolezn Pertesa: etiologiia, klinika, patogenez, metody lecheniia [Legg-Calvé-Perthes' disease: ethiology, clinical picture, pathogenesis, methods of treatment]. Meditsinskie Novosti, 2013, no. 7, pp. 18-24. (in Russian)

8. Skvortsov D.V., Ivanova G.E., Poliaev B.A., Stakhovskaia L.V. Diagnostika i testirovanie dvigatelnoi patologii instrumentalnymi sredstvami [Diagnosis and testing of motor pathology by instrumental means]. Vestnik Vosstanovitelnoi Meditsiny, 2013, no. 5, pp. 74-78. (in Russian)

9. Biriukova E.V., Gurev V.V., Zoria V.I., Prokopenko R.A., Frolov A.A. Biomekhanicheskii analiz pokazatelei dvizhenii v tazobedrennom, kolennom i golenostopnom sustavakh u bolnykh s koksartrozom kak metod funktsionalnoi diagnostiki [Biomechanical analysis of movement values in the hip, the knee and the ankle in patients with coxarthrosis as a method of functional diagnostics]. Biulleten VSNTS SO RAMN, 2010, no. 6 (76), part 1, pp. 21-30. (in Russian)

10. Ivanova G.E., Skvortsov D.V. Obektivnyi klinicheskii analiz pokhodki. Obzor [Objective clinical gait analysis. An overview]. Vestnik Vosstanovitelnoi Meditsiny, 2015, no. 4, pp. 59-66. (in Russian) 
11. Muro-de-la-Herran A., Garcia-Zapirain B., Mendez-Zorrilla A. Gait analysis methods: an overview of wearable and non-wearable systems, highlighting clinical applications. Sensors (Basel), 2014, vol. 14, no. 2, pp. 3362-3394. DOI: 10.3390/s140203362

12. Akhpashev A.A., Zagorodnii N.V., Kanaev A.S., Kaurkin S.N., Skvortsov D.V. Funktsiia kolennogo sustava vo vremia khodby u bolnykh s razryvom perednei krestoobraznoi sviazki kolennogo sustava do i posle operativnogo lecheniia [The knee function during walking in patients with the knee cruciate ligament rupture before and after surgical treatment]. Travmatologiia i Ortopediia Rossii, 2016, vol. 22, no. 2, pp. 15-24. (in Russian)

13. Qiu S., Wang Z., Zhao H., Hu H. Using Distributed Wearable Sensors to Measure and Evaluate Human Lower Limb Motions. IEEE Transactions on Instrumentation and Measurement, 2016, vol. 65, no. 4, pp. 939-950. DOI: 10.1109/TIM.2015.2504078

14. Wang Z., Qiu S., Cao Z., Jiang M. Quantitative assessment of dual gait analysis based on inertial sensors with body sensor network. Sensor Review, 2013 , vol. 33 , no. 1 , pp. 48-56. DOI: $10.1108 / 02602281311294342$

15. Yoo J.I., Cha Y.H., Kim K.J., Kim H.Y., Choy W.S., Hwang S.C. Gait analysis after total hip arthroplasty using direct anterior approach versus anterolateral approach: a systematic review and meta-analysis. BMC Musculoskelet. Disord., 2019, vol. 20, no. 1, pp. 63. DOI: 10.1186/s12891-019-2450-2

16. Rasch A., Dalén N., Berg H.E. Muscle strength, gait, and balance in 20 patients with hip osteoarthritis followed for 2 years after THA. Acta Orthop., 2010, vol. 81, no. 2, pp. 183-188. DOI: 10.3109/17453671003793204

17. Rueterbories J., Spaich E.G., Larsen B., Andersen O.K. Methods for gait event detection and analysis in ambulatory systems. Med. Eng. Phys., 2010, vol. 32, no. 6, pp. 545-552. DOI: 10.1016/j.medengphy.2010.03.007

18. Titarenko N.Iu., Titarenko K.E., Levchenkova V.D., Semenova K.A., Voronov A.V., Dotsenko V.I., Smirnov I.E. Kolichestvennaia otsenka narushenii dvigatelnykh funktsii u bolnykh detskim tserebralnym paralichom metodom videoanaliza dvizhenii s ispolzovaniem dvukhmernoi biomekhanicheskoi modeli [Quantitative evaluation of motor function disorders in patients with infantile cerebral palsy with motion video analysis using a two-dimensional biomechanical model]. Rossiiskii Pediatricheskii Zhurnal, 2014, no. 5, pp. 20-26. (in Russian)

19. Avvenuti M., Carbonaro N., Cimino M.G.C.A., Cola G., Tognetti A., Vaglini G. Smart shoe-assisted evaluation of using a single trunk/pocket-worn accelerometer to detect gait phases. Sensors, 2018, vol. 18, no. 11, pp. 3811-3824. DOI: 10.3390/s18113811

20. Attinger D., Luethi S., Stuessi E. Objective evaluation of gait asymmetry (abstract). $5^{\text {th }}$ Meet. of the Europ. Soc. of Biomech. Berlin, 1986. P. 563-568.

21. Skvortsov D.V. Diagnostika dvigatelnoi patologii instrumentalnymi metodami: analiz pokhodki, stabilometriia [Diagnosing motor pathology by instrumental methods: gait analysis, stabilometry]. M., T.M. Andreeva, 2007, 640 p. (in Russian)

22. Renström A.F. Mechanism, diagnosis and treatment of running injuries. Instr. Course Lect., 1993, vol. 42, pp. 225-234.

23. Zügner R., Tranberg R., Lisovskaja V., Kärrholm J. Different reliability of instrumented gait analysis between patients with unilateral hip osteoarthritis, unilateral hip prosthesis and healthy controls. BMC Musculoskelet. Disord., 2018, vol. 19, no. 1, pp. 224. DOI: 10.1186/s12891-018-2145-0

24. Peng Y., Arauz P., Desai P., Byers A., Klemt C., Kwon Y.M. In vivo kinematic analysis of patients with robotic-assisted total hip arthroplasty during gait at 1-year follow-up. Int. J. Med. Robot., 2019, vol. 15, no. 5, pp. e2021. DOI: 10.1002/rcs.2021

25. Minasov B.Sh., Iakupov R.R., Askarov A.F., Khairov T.E., Sirodzhov K.Kh., Karimov K.K., Shurmelev K.I. Sravnitelnyi analiz rezultatov artroplastiki tazobedrennogo sustava na osnove biometrii faz opory i khodby [A comparative analysis of the hip arthroplasty results based on the support and walking phases]. Meditsinskii Vestnik Bashkortostana, 2015, vol. 10 (58), no. 4, pp. 35-40. (in Russian)

26. Efimov A.A. Informativnost biomekhanicheskikh parametrov pokhodki dlia otsenki patologii nizhnikh konechnostei [Infoemation value of gait biomechanical parameters for evaluation of the lower limb pathology]. Rossiiskii Zhurnal Biomekhaniki, 2012, vol. 16, no. 1 (55), pp. 80-88. (in Russian)

27. Kumar S.N., Omar B., Joseph L.H., Htwe O., Jagannathan K., Hamdan N.M., Rajalakshmi D. Evaluation of limb load asymmetry using two new mathematical models. Glob. J. Health Sci., 2014, vol. 7, no. 2, pp. 1-7. DOI: 10.5539/gjhs.v7n2p1

28. Wenger D.R., Pandya N.K. Advanced containment methods for the treatment of Perthes disease: Salter plus varus osteotomy and triple pelvic osteotomy. J. Pediatr. Orthop., 2011, vol. 31, no. 2 Suppl., pp. S198-S205. DOI:10.1097/bpo.0b013e31822602b0

29. Shchurov V.A., Novikov K.I., Muradisinov S.O. Vliianie raznovysokosti nizhnikh konechnostei na biomekhanicheskie parametry khodby [The effect of the lower limb different length on biomechanical walking parameters]. Rossiiskii Zhurnal Biomekhaniki, 2011, vol. 15, no. 4 (54), pp. 102-107. (in Russian)

30. Nikitiuk I.E., Garkavenko Iu.E., Kononova E.L. Osobennosti opornoi funktsii nizhnikh konechnostei u detei s posledstviiami porazheniia proksimalnogo otdela bedra ostrym gematogennym osteomielitom [The particular qualities of the lower limb support function in children with consequences of proximal femur affection with acute hematogenous osteomyelitis]. Ortopediia, Travmatologiia $i$ Vosstanovitelnaia Khirurgiia Detskogo Vozrasta, 2018, vol. 6, no. 1, pp. 14-22. (in Russian) DOI: 10.17816/PTORS5349-57

31. Aidarov V.I., Skvortsov A.P. Formirovanie pravilnogo dvigatelnogo stereotipa khodby u patsientov s defitsitom lokomotornykh funktsii nizhnikh konechnostei [Formation of the correct motor gait stereotype in patients with deficits of the lower limb locomotor functions]. Prakticheskaia Meditsina, 2013, vol. 2, no. 1-2 (69), pp. 12-13. (in Russian)

32. Balsevich V.K. Ocherki po vozrastnoi kineziologii cheloveka [Essays on human age kinesiology]. M., Sovetskii Sport, 2009, 220 p. (in Russian)

33. Nikitiuk I.E., Kononova E.L., Garkavenko Iu.E. Osobennosti narusheniia balansa tela u detei s odnostoronnim ukorocheniem nizhnei konechnosti [The special features of body balance disorder in children with unilateral shortening of the lower limb]. Ortopediia, Travmatologiia $i$ Vosstanovitelnaia Khirurgiia Detskogo Vozrasta, 2019, vol. 7, iss. 3, pp. 45-54. (in Russian) DOI: 10.17816/PTORS7345-54

Received: 10.03 .2020

\section{Information about the authors:}

1. Alexey G. Baindurashvili, M.D., Ph.D., Professor, Member Of RAS, Honored Doctor of the Russian Federation, H. Turner National Medical Research Center for Children's Orthopedics and Trauma Surgery, Saint Petersburg, Russian Federation, ORCID: https://orcid.org/0000-0001-8123-6944, Email: turner01@mail.ru

2. Igor E. Nikityuk, M.D., Ph.D.,

H. Turner National Medical Research Center for Children's Orthopedics and Trauma Surgery, Saint Petersburg, Russian Federation, ORCID: https://orcid.org/0000-0001-5546-2729,

Email: femtotech@mail.ru

3. Ekaterina A. Kostomarova,

H. Turner National Medical Research Center for Children's Orthopedics and Trauma Surgery, Saint Petersburg, Russian Federation, ORCID: https://orcid.org/0000-0002-6898-3213,

Email: ekaterina.kostomarova@mail.ru

4. Elizaveta L. Kononova, M.D., Ph.D.,

H. Turner National Medical Research Center for Children's Orthopedics and Trauma Surgery, Saint Petersburg, Russian Federation, ORCID: https://orcid.org/0000-0001-7624-013X,

Email: Yelisaveta@yandex.ru

5. Dmitry B. Barsukov, M.D., Ph.D.,

H. Turner National Medical Research Center for Children's Orthopedics and Trauma Surgery, Saint Petersburg, Russian Federation, ORCID: https://orcid.org/0000-0002-9084-5634,

Email: dbbarsukov@gmail.com

6. Vladimir E. Baskov, M.D., Ph.D.,

H. Turner National Medical Research Center for Children's Orthopedics and Trauma Surgery, Saint Petersburg, Russian Federation, ORCID: https://orcid.org/0000-0003-0647-412X,

Email: dr.baskov@mail.ru 